\title{
PENGARUH DIFERENSIASI PRODUK DAN SALURAN DISTRIBUSI TERHADAP LOYALITAS PELANGGAN PADA CV. MAKMUR AUTO SEJAHTERA MEDAN
}

\author{
Sri Rezeki ${ }^{1}$, Desma Erica Maryati $\mathbf{M}^{2}$, Ihdina Gustina ${ }^{3}$ \\ Manajemen, STIE Eka Prasetya
}

\begin{abstract}
This study aims to determine the effect of product differentiation on customer loyalty on CV. Makmur Auto Sejahtera Medan, knows the effect of distribution channels on customer loyalty on CV. Makmur Auto Sejahtera Medan, and find out the effect of product differentiation and distribution channels on customer loyalty on CV. Makmur Auto Sejahtera Medan. The research methodology used is descriptive quantitative method, the unit of analysis in this study is CV. Makmur Auto Sejahtera Medan and its observation unit are CV customers. Makmur Auto Sejahtera Medan. The population in this study is CV. Makmur Auto Sejahtera Medan as many as 62 permanent customers. The sampling technique in this study used saturated samples. Thus, the number of research samples used was 62 permanent customers. Data were analyzed using the method of multiple linear regression analysis. The results of the analysis give the equation Customer Loyalty $=$ 0,108+ 0,249ProductDifferentiation + 0,383DistributionChannels $+\mathbf{e}$. The results of the study partially indicate that product differentiation has a positive and significant effect on customer loyalty CV. Makmur Auto Sejahtera Medan. This is evidenced from the acquisition of $t_{\text {arithmetic }} 4.834>t_{\text {table }} 1.67065$ and a significant value of $0,000<0.05$ and the distribution channel has a positive and significant effect on customer loyalty $C V$. Makmur Auto Sejahtera Medan. This is evidenced from the acquisition of the value of $t_{\text {arithmetic }} 4.818>t_{\text {table }} 1.67065$ and a significant value of $0.000<0.05$. Simultaneously, product differentiation and distribution channels simultaneously have a positive and significant effect on customer loyalty CV. Makmur Auto Sejahtera Medan. This is evidenced from the acquisition of the calculated $F_{\text {arithmetic }} 30,308>F_{\text {table }} 3,15$ and a significant value of $0,000<0.05$. Product differentiation and distribution channels can explain customer loyalty by $49.0 \%$ and the remaining $51.0 \%$ is influenced by other variables outside of this study such as customer satisfaction, brand and price.
\end{abstract}

Keywords : Product Differentiation, Distribution Channel, Customer Loyalty

\section{PENDAHULUAN}

Perusahaan yang ingin bertahan harus mempunyai nilai lebih yang menjadikan perusahaan tersebut berbeda dengan perusahaan lain. Nilai lebih yang ditawarkan ini akan semakin memantapkan pilihan kepada calon pelanggan untuk bertransaksi atau mendorong para pelanggan lama untuk bertransaksi kembali. Perusahaan yang memiliki kemampuan dalam meningkatkan loyalitas pelanggan secara berkesinambungan akan dapat bertahan dari persaingan bisnis yang ketat dikarenakan loyalitas pelanggan merupakan faktor yang sangat penting dalam kelangsungan hidup perusahaan.

CV. Makmur Auto Sejahtera Medan merupakan perusahaan yang bergerak di bidang penjualan sparepart mobil. Perusahaan ini berada di jalan Bogor No. 105 Medan. Pelanggan perusahaan meliputi toko sparepart mobil, showroom, dan perusahaan yang menjual mobil. Sparepart mobil yang paling banyak dijual perusahaan adalah sparepart mobil merek Toyota. Produk sparepart mobil yang dijual perusahaan seperti ban, velg mobil, audio dan video mobil, knalpot mobil, baterai, lampu mobil. Pada tahun 2018, jumlah pelanggan tetap perusahaan tercatat sebanyak 62 pelanggan dan mengalami 
penurunan dibandingkan dengan tahun sebelumnya. Hal ini mencerminkan loyalitas pelanggan di perusahaan mengalami penurunan sehingga pelanggan beralih ke perusahaan lain dalam bertransaksi.

Penurunan loyalitas pelanggan disinyalir karena faktor diferensiasi produk dan saluran distribusi. Dalam faktor diferensiasi produk, produk sparepart mobil yang dijual perusahaan saat ini kebanyakan juga dijual perusahaan lain. Perusahaan tidak mengupayakan untuk menjual produk sparepart mobil yang lebih jarang dijual perusahaan lain seperti dengan mensuplai dari negara lain produk sparepart mobil yang masih jarang dijual di Indonesia.

Dalam faktor saluran distribusi, pelanggan sering mengeluhkan bahwa distribusi produk ke tempat pelanggan sering mengalami keterlambatan. Hal ini disebabkan perusahaan belum menggunakan sistem informasi yang dapat mempercepat proses penyaluran distribusi sehingga staf perusahaan sulit mengatur dan mengelola antrian pengiriman produk dengan baik yang mengakibatkan suatu tempat tujuan yang saling berdekatan dapat dikirim lebih dari 1 kali. Kurangnya armada/mobil pengangkutan dan tenaga kerja juga menyebabkan produk terlambat untuk disalurkan ke tempat pelanggan.

Loyalitas pelanggan merupakan perilaku yang terkait dengan merek sebuah produk, termasuk kemungkinan memperbaharui kontrak mereka di masa yang akan datang, berapa kemungkinan pelanggan untuk meningkatkan citra positif suatu produk. Perusahaan yang mampu mengikat loyalitas pelanggan akan membuat perusahaan semakin berkembang dan mengurangi pengaruh serangan dari para kompetitor dari perusahaan sejenis. Loyalitas pelanggan merupakan aset yang sangat berharga bagi setiap perusahaan karena dengan membuat pelanggan loyal, maka mereka akan memiliki komitmen terhadap merek yang kemudian akan mendatangkan profit bagi perusahaan. Pelanggan yang loyal cenderung akan memutuskan pembelian produk pada perusahaan karena mereka yakin, percaya, dan setia kepada perusahaan.

CV. Makmur Auto Sejahtera merupakan salah satu perusahaan yang bergerak di bidang penjualan sparepart mobil di mana mendistribusikan sparepart mobil merek Toyota kepada pelanggannya. CV. Makmur Auto Sejahtera didirikan oleh Bapak Harun Widjaja pada tanggal 30 Oktober 2010 yang beralamatkan di jalan Bogor No. 105, Medan

\section{TELAAH PUSTAKA DAN HIPOTESIS}

\section{Loyalitas Pelanggan}

Menurut Hasan (2014) loyalitas pelanggan merupakan prilaku yang terkait dengan merek sebuah produk termasuk kemungkinan memperbaharui kontrak merek di masa yang akan datang dan berapa kemungkinan pelanggan untuk meningkatkan citra positif suatu produk. Dan menurut Hasan (2014) ada 4 indikator loyalitas pelanggan, antara lain : 1)Adanya tuntunan pembelian dan proporsi pembelian atau probabilitas pembelian, 2)Tingat atau ukuran kedekatan pelanggan pada sebuah merek, 3) Adanya perasaan positif terhadap merek, 4)Penggunaan merek yang sama secara teratur.

\section{Diferensiasi Produk}

Menurut Wibowo dan Priansa (2017) diferensiasi produk adalah proses menambahkan serangkaian perbedaan yang penting dan bernilai guna membedakan tawaran perusahaan itu dari tawaran pesaing. Dan menurut Hasan (2014) ada 7 indikator diferensiasi produk, antara lain : 1)Bentuk produk, 2) Fitur, 3)Kinerja, 4)Kesesuaian 
mutu dengan standar yang ada, 5)Daya tahan, 6)Keandalan, 7)Kemudahan untuk diperbaiki.

\section{Saluran Distribusi}

Menurut Kotler dan Keller (2013) saluran distribusi adalah sekelompok organisasi yang saling bergantung dan terlibat dalam proses pembuatan produk atau jasa yang disediakan untuk digunakan atau dikonsumsi. Dan menurut Kotler dan Keller (2013) ada 5 indikator saluran distibusi, antara lain : 1) Ukuran lot, 2) Waktu tunggu dan waktu pengiriman, 3) Kenyamanan spasial, 4) Keragaman produk, 5) Dukungan layanan.

Berikut pengujian hipotesis penelitiannya :

$\mathrm{H}_{1}$ : Terdapat pengaruh positif dan signifikan Diferensiasi Produk terhadap Loyalitas Pelanggan pada CV. Makmur Auto Sejahtera Medan.

$\mathrm{H}_{2}$ : Terdapat pengaruh positif dan signifikan Saluran Distribusi terhadap Loyalitas Pelanggan pada CV. Makmur Auto Sejahtera Medan.

$\mathrm{H}_{3}$ : Terdapat pengaruh positif dan signifikan Diferensiasi Produk dan Saluran Distribusi terhadap Loyalitas Pelanggan pada CV. Makmur Auto Sejahtera Medan.

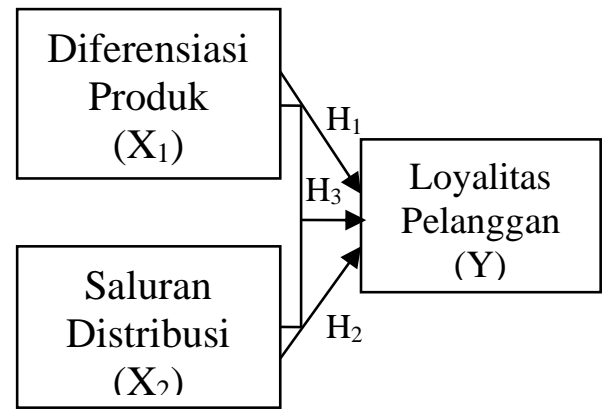

\section{METODOLOGI PENELITIAN}

\section{Lokasi Penelitian}

Lokasi penelitian ini adalah perusahaan CV. Makmur Auto Sejahtera yang beralamat di jalan Bogor No. 105, Medan.

\section{Populasi dan Sampel}

Dalam penelitian ini, populasi yang digunakan adalah pelanggan pada CV. Makmur Auto Sejahtera sebanyak 62 responden.

Teknik pengambilan sampel dalam penelitian ini adalah dengan menggunakan sampel jenuh. Sampel penelitian ini sebanyak 62 pelanggan.

\section{Teknik Pengumpulan Data}

Teknik pengumpulan data yang digunakan adalah kuesioner. Menurut Sujarweni (2018:120-121), "Kuesioner merupakan teknik pengumpulan data yang dilakukan dengan cara memberikan seperangkat pertanyaan atau pernyataan tertulis kepada para responden untuk dijawab". Kuesioner ini dibagikan kepada pelanggan tetap CV. Makmur Auto Sejahtera Medan untuk diisi.

\section{Metode Analisis}

Menurut Sujarweni (2015:160), "Analisis regresi digunakan untuk mengetahui pengaruh variabel independen terhadap variabel dependen. Selain itu juga analisis regresi 
digunakan untuk menguji kebenaran hipotesis yang diajukan dalam penelitian". Model analisis data yang digunakan dalam penelitian ini adalah analisis regresi linear berganda yang digunakan untuk mengetahui seberapa besar pengaruh diferensiasi produk dan saluran distribusi terhadap loyalitas pelanggan pada CV. Makmur Auto Sejahtera Medan dengan menggunakan bantuan perangkat lunak Statistical Product and Service Solution (SPSS) versi 17 dengan rumus:

Keterangan :

$$
\mathbf{Y}=\alpha+\beta_{1} \mathbf{X}_{1}+\beta_{2} \mathbf{X}_{2}+e
$$

Y= Loyalitas Pelanggan (dependent variable)

$\mathrm{X}_{1}=$ Diferensiasi Produk (independent variable)

$\mathrm{X}_{2}=$ Saluran Distribusi (independent variable)

$\alpha=$ konstanta

$\beta_{1}=$ koefisien untuk variabel Diferensiasi Produk

$\beta_{2}=$ koefisien untuk variabel Saluran Distribusi

$\mathrm{e}=$ presentase kesalahan $(5 \%)$

\section{HASIL DAN PEMBAHASAN}

\section{Karakteristik Responden}

Karakteristik responden berdasarkan bidang jasa yaitu responden Penjualan sparepart sebanyak 37 orang $(59,7 \%)$, responden Penjualan mobil sebanyak 10 orang $(16,1 \%)$, responden Showroom, Bengkel, dan lainnya ada sebanyak 5 orang $(8,1 \%)$ Dengan demikian, responden terbanyak dalam penelitian ini adalah responden yang memiliki bidang jasa penjualan sparepart di mana mencerminkan produk sparepart mobil yang dijual perusahaan lebih dibeli oleh pelanggan yang memiliki usaha yang sejenis.

Karakteristik responden berdasarkan jenis kelamin yaitu responden Laki-laki sebanyak 51 orang $(82,3 \%)$ dan responden Perempuan sebanyak 11 orang $(17,7 \%)$. Dengan demikian, responden terbanyak dalam penelitian ini adalah responden yang berjenis kelamin laki-laki di mana mencerminkan pelanggan laki-laki lebih menyukai produk dan usaha sparepart mobil.

Karakteristik responden berdasarkan tingkat pendidikan yaitu responden Sarjana sebanyak 12 orang $(19,4 \%)$, responden Diploma sebanyak 39 orang $(62,9 \%)$, responden S1 sebanyak 6 orang $(9,7 \%)$, responden S2 sebanyak 3 orang $(4,8 \%)$, dan responden lainnya sebanyak 2 orang $(3,2 \%)$. Dengan demikian, responden terbanyak dalam penelitian ini adalah responden yang berpendidikan diploma, sehingga dapat disimpulkan bahwa mayoritas pelanggan perusahaan memiliki tingkat pendidikan yang tidak terlalu tinggi.

Karakteristik responden berdasarkan penghasilan perbulan yaitu responden dengan penghasilan $<500$ juta sebanyak 46 orang $(74,2 \%)$, responden dengan penghasilan 500 juta-1M sebanyak 6 orang $(9,7 \%)$, responden dengan penghasilan $1 \mathrm{M}-2 \mathrm{M}$ sebanyak 8 orang $(12,9 \%)$, dan responden dengan penghasilan $>2 \mathrm{M}$ sebanyak 2 orang $(3,2 \%)$. Dengan demikian, mayoritas pelanggan perusahaan memiliki penghasilan per bulan kurang dari 500 juta.

\section{Uji Validitas dan Uji Reabilitas}

Menurut Ghozali (2013), mengukur validitas dapat dilakukan dengan cara melakukan korelasi antar skor butir pertanyaan dengan total skor konstruk atau variabel. Uji signifikansi dilakukan dengan membandingkan nilai $r_{\text {hitung }}$ dengan $r_{\text {tabel }}$ untuk degree of freedom $(\mathrm{df})=\mathrm{n}-2$, dalam ini adalah jumlah sampel. Jadi (df) yang digunakan adalah 30-2 $=28$ dengan alpha sebesar 5\% maka menghasilkan nilai $r_{\text {tabel }}$ (uji dua sisi) sebesar 0,361 . Jika $r_{\text {hitung }}$ pada tiap butir pernyataan lebih besar daripada $r_{\text {tabel }}$ dan nilai $r$ positif makan pernyataan tersebut dinyatakan valid. 
Menurut Priyatno (2016:60) "Untuk penentuan apakah instrumen reliabel atau tidak, bisa digunakan batasan tertentu seperti 0.6. Reliabilitas kurang dari 0.6 adalah kurang baik, sedangkan 0.7 dapat diterima, dan di atas 0.8 adalah baik". Hasil uji Validitas dan Reliabilitas akan disajikan pada tabel 1. Dan tabel 2.

Tabel 1. Hasil Uji Validitas

\begin{tabular}{lllr}
\hline No & Pernyataan & Variabel & rhitung \\
\hline 1. & DF-1 & Diferensiasi & 0,750 \\
2. & DF-2 & Produk & 0,495 \\
3. & DF-3 & & 0,802 \\
4. & DF-4 & & 0,757 \\
5. & DF-5 & & 0,817 \\
6. & DF-6 & & 0,791 \\
7. & DF-7 & & 0,703 \\
\hline 1. & SD-1 & Saluran & 0,855 \\
2. & SD-2 & Distribusi & 0,912 \\
3. & SD-3 & & 0,660 \\
4. & SD-4 & & 0,920 \\
5. & SD-5 & & 0,912 \\
\hline 1. & LP-1 & Loyalitas & 0,418 \\
2. & LP-2 & Pelanggan & 0,863 \\
3. & LP-3 & & 0,863 \\
4. & LP-4 & & 0,625
\end{tabular}

Sumber: Data Primer (diolah), 2019

Dari hasil tabel 1 diperoleh nilai $r$ hitung dari masing-masing item pernyataan untuk setiap variable diperoleh di atas 0,361 sehingga dapat dikatakan pernyataan yang digunakan dalam variable penelitian dikatakan validitas.

Tabel 2. Hasil Uji Reliabilitas

\begin{tabular}{llcc}
\hline No & Variabel & $\begin{array}{l}\text { Jumlah } \\
\text { Item }\end{array}$ & $\begin{array}{l}\text { Cronbach's } \\
\text { Alpha }\end{array}$ \\
\hline 1. & $\begin{array}{l}\text { Diferensiasi } \\
\text { Produk }\end{array}$ & 7 & 0,906 \\
2. & $\begin{array}{l}\text { Saluran } \\
\text { Distribusi }\end{array}$ & 5 & 0,941 \\
3. & $\begin{array}{l}\text { Loyalitas } \\
\text { Pelanggan }\end{array}$ & 4 & 0,834 \\
\hline
\end{tabular}

Dan dari tabel 2 juga diperoleh dari masing-masing variable di Cronbach's alpha tidak dibawah 0,6 sehingga dapat dinyatakan realible, distribusi kumulatif dari distribusi normal. 


\section{Uji Asumsi Klasik}

\section{Uji Normalitas}

Histogram

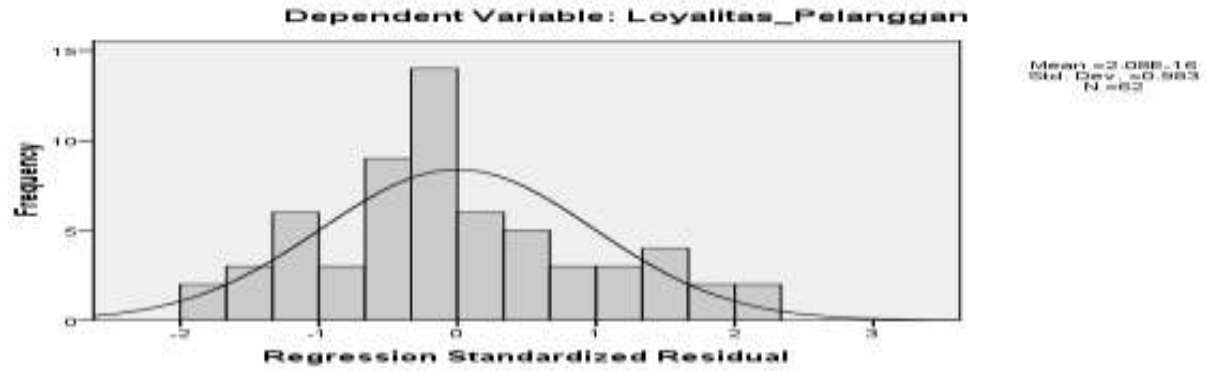

Gambar 2. Grafik Histogram

Dari Gambar 2 dapat diperoleh data riil membentuk garis kurva cenderung simetri tidak melenceng ke kiri atau pun ke kanan sehingga dapat disimpulkan bahwa data berdistribusi normal.

\section{Uii Normalitas Normal P-Plot}

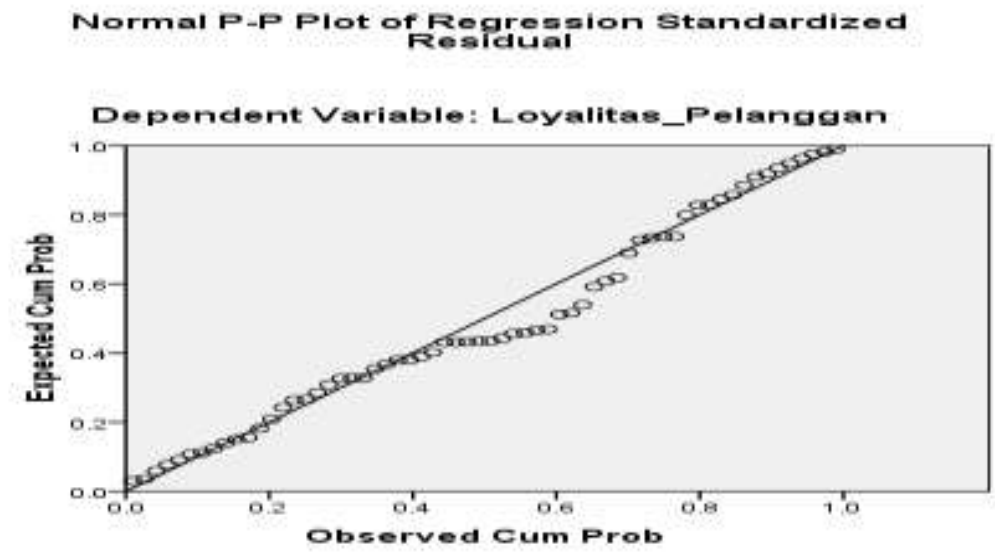

Gambar 3. Grafik Normal P-Plot

Gambar ini dilihat bahwa data tersebar disekitar garis diagonal sehingga dapat disimpulkan data terdistribusi normal.

\section{Uji Normalitas Kolmogrov Smirnov}

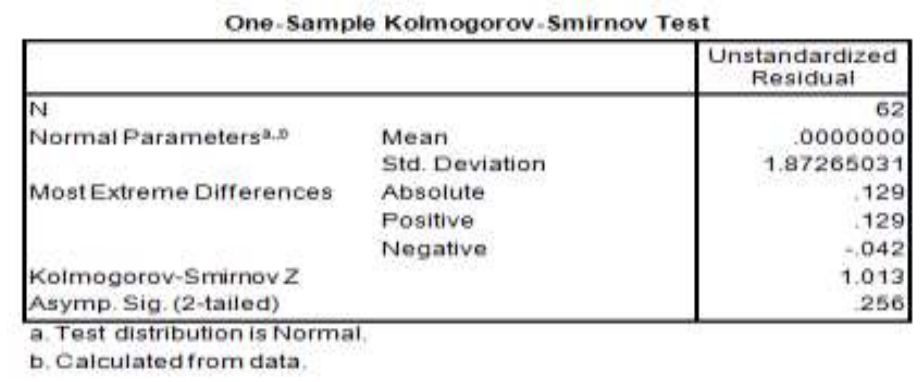


Berdasarkan tabel 3 diatas, menunjukkan bahwa nilai signifikannya adalah 0,256 yang lebih besar dari 0,05 sehingga dapat disimpulkan bahwa data telah berdistribusi normal.

\section{Uji Multikolinearitas}

Tabel 4. Uji Multikolinearitas

\section{Coefficients ${ }^{\mathrm{a}}$}

\begin{tabular}{|ll|r|r|}
\hline \multirow{2}{*}{ Model } & \multicolumn{2}{|c|}{ Collinearity Statistics } \\
\cline { 3 - 4 } & & Tolerance & \multicolumn{1}{c|}{ VIF } \\
\hline 1 & Diferensiasi_Produk & .946 & 1.057 \\
& Saluran_Distribusi & .946 & 1.057 \\
\hline
\end{tabular}

a. DependentVariable:Loyalitas_Pelanggan

Berdasarkan tabel 4 di atas, dapat dilihat bahwa variabel diferensiasi produk dan saluran distribusi mempunyai nilai tolerance $0,946>0,1$ dan nilai VIF $1,057<10$ sehingga dapat disimpulkan bahwa pada kedua variabel tidak terjadi gejala multikolinearitas.

\section{Uji Heteroskedastisitas}

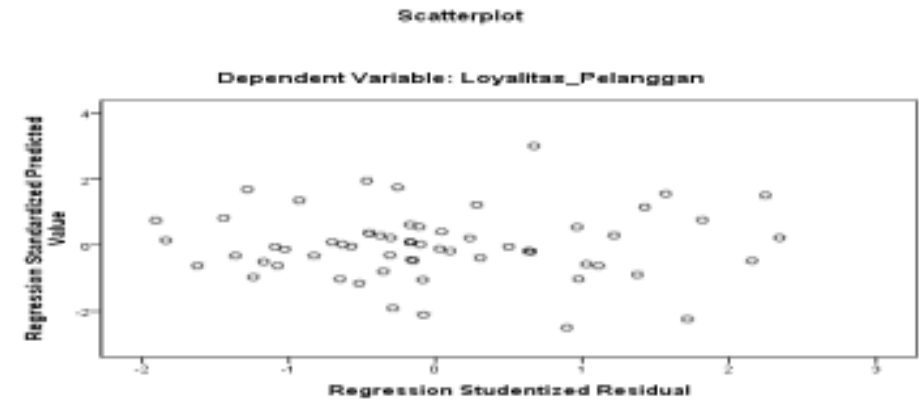

Gambar 4. Grafik Scatterplot

Pada Gambar 4 di atas, dapat dilihat bahwa data menyebar dengan pola tidak jelas baik diatas maupun dibawah angka nol (0) pada sumbu Y, tidak berkumpul disatu tempat, dapat disimpulkan bahwa tidak terjadi heteroskedatisitas.

\section{Hasil Analisis Regresi Linier Berganda}

Tabel 5. Standardized Coefficients Coefficients $^{\mathrm{a}}$

\begin{tabular}{|c|c|c|c|c|c|c|}
\hline \multirow{2}{*}{\multicolumn{2}{|c|}{ Model }} & \multicolumn{2}{|c|}{ Unstandardized Coefficients } & \multirow{2}{*}{$\begin{array}{c}\text { Standardized } \\
\text { Coefficients }\end{array}$} & \multirow[b]{2}{*}{$t$} & \multirow[b]{2}{*}{ Sig. } \\
\hline & & B & Std. Error & & & \\
\hline \multirow[t]{3}{*}{1} & (Constant) & .108 & 1.186 & & .091 & .928 \\
\hline & Diferensiasi_Produk & .249 & .052 & .454 & 4.834 & .000 \\
\hline & Saluran_Distribusi & .383 & .080 & .453 & 4.818 & .000 \\
\hline
\end{tabular}

a.DependentVariable:Loyalitas_Pelanggan 
Dari tabel 5, uji regresi linear berganda diperoleh persamaan regresinya adalah:

\section{Loyalitas Pelanggan = 0,108 + 0,249 Diferensiasi Produk + 0,383 Saluran Distribusi +}

e

Penjelasan persamaan sebagai berikut:

1. 0,108 artinya apabila nilai diferensiasi produk dan saluran distribusi 0 atau tidak ada, maka loyalitas pelanggan pada perusahaan tersebut bernilai 0,108 .

2. 0,249 bernilai positif, artinya diferensiasi produk mempunyai hubungan positif dengan loyalitas pelanggan. Apabila diferensiasi produk bernilai 1, maka loyalitas pelanggan perusahaan akan meningkat sebesar 0,249

3. 0,383 bernilai positif, artinya saluran distribusi mempunyai hubungan positif dengan loyalitas pelanggan. Apabila saluran distribusi bernilai 1, maka loyalitas pelanggan perusahaan akan meningkat sebesar 0,383 .

\section{Hasil Pengujian Hipotesis}

\section{Uji t (Uji Parsial)}

Uji t digunakan untuk melihat secara parsial apakah ada pengaruh yang signifikan dari variabel bebas terhadap variabel terikat. Bentuk pengujiannya adalah sebagai berikut:

1. H0 : $\beta 1=\beta 2=0$, artinya Diferensiasi Produk, Saluran Distribusi secara parsial tidak berpengaruh terhadap Loyalitas Pelanggan pada CV. Makmur Auto Sejahtera Medan

2. H1 : $\beta 1 \quad \beta 2 \neq 0$, artinya Diferensiasi Produk, Saluran Distribusi secara parsial berpengaruh terhadap Loyalitas Pelanggan pada CV. Makmur Auto Sejahtera Medan

Tabel 6. Uii Parsial

\begin{tabular}{|c|c|c|c|c|c|c|}
\hline \multirow{2}{*}{\multicolumn{2}{|c|}{ Model }} & \multicolumn{2}{|c|}{ Unstandardized Coefficients } & \multirow{2}{*}{$\begin{array}{c}\text { Standardized } \\
\text { Coefficients }\end{array}$} & \multirow[b]{2}{*}{$\mathrm{t}$} & \multirow[b]{2}{*}{ Sig. } \\
\hline & & B & Std. Error & & & \\
\hline \multirow[t]{3}{*}{1} & (Constant) & .108 & 1.186 & & .091 & .928 \\
\hline & Diferensiasi_Produk & 249 & .052 & .454 & 4.834 & .000 \\
\hline & Saluran_Distribusi & .383 & .080 & .453 & 4.818 & .000 \\
\hline
\end{tabular}

Dari tabel 6, diperoleh nilai thitung untuk variabel Diferensiasi Produk adalah 4,834 dengan signifikan 0,000. Dengan derajat bebas (df) sebesar 60 dan taraf sig $\alpha=5 \%$ maka nilai tabel adalah sebesar 1,67065. Nilai thitung $>t$ tabel maka kriterianya adalah H0 ditolak sehingga Diferensiasi Produk secara parsial berpengaruh dan signifikan terhadap Loyalitas Pelanggan. Dan nilai thitung untuk variabel Saluran Distribusi adalah 4,818 dengan signifikan 0,000 . Dengan derajat bebas (df) sebesar 60 dan taraf sig $\alpha=5 \%$ maka nilai tabel adalah sebesar 1,67065. Oleh karena nilai thitung > ttabel maka kriterianya adalah H0 ditolak sehingga Saluran Distribusi secara parsial berpengaruh dan signifikan terhadap Loyalitas Pelanggan.

\section{Uji F (Uji Serempak)}

Uji F pada dasarnya menunjukkan apakah semua variabel bebas yang dimasukkan dalam model mempunyai pengaruh secara simultan terhadap variabel dependen. Uji $F$ digunakan untuk menguji pengaruh dimensi variabel bebas secara serempak terhadap variabel terikat. Bentuk pengujiannya adalah sebagai berikut: 
1. $\mathrm{H} 0: \beta 1=\beta 2=0$, artinya Diferensiasi Produk, Saluran Distribusi secara serempak tidak berpengaruh terhadap Loyalitas Pelanggan pada CV. Makmur Auto Sejahtera Medan

2. $\mathrm{H} 1: \beta 1=\beta 2 \neq 0$, artinya Diferensiasi Produk, Saluran Distribusi secara serempak berpengaruh terhadap Loyalitas Pelanggan pada CV. Makmur Auto Sejahtera Medan

Tabel 7. Uji Simultan

ANOVA $^{\mathrm{B}}$

\begin{tabular}{|c|c|c|c|c|c|c|}
\hline \multicolumn{2}{|c|}{ Model } & Sum of Squares & df & Mean Square & $\mathrm{F}$ & Sig. \\
\hline \multirow[t]{3}{*}{1} & Regression & 219.778 & 2 & 109.889 & 30.308 & $.000^{3}$ \\
\hline & Residual & 213.916 & 59 & 3.626 & & \\
\hline & Total & 433.694 & 61 & & & \\
\hline
\end{tabular}

Berdasarkan tabel diatas, diketahui nilai $\mathrm{F}_{\text {hitung }}$ adalah 30,308 dimana nilainya lebih besar daripada $\mathrm{F}_{\text {tabel }} 3,15$. Untuk nilai signifikan juga terlihat $0,000<0.05$ yang berarti hasil uji hipotesis ini menunjukkan bahwa variabel diferensiasi produk dan saluran distribusi secara simultan berpengaruh positif dan signifikan terhadap loyalitas pelanggan CV. Makmur Auto Sejahtera Medan.

\section{Uji Koefisien Determinasi $\left(\mathbf{R}^{2}\right)$}

Koefisien determinasi (R2) pada intinya mengukur seberapa jauh kemampuan model dalam menerangkan variasi variabel dependen.

Tabel 8. Uji Determinasi

Model Summary ${ }^{\mathrm{b}}$

\begin{tabular}{l|c|r|c|c|r|}
\hline Model & $\mathrm{R}$ & $\mathrm{R}$ Square & $\begin{array}{c}\text { Adjusted R } \\
\text { Square }\end{array}$ & $\begin{array}{c}\text { Std. Error of the } \\
\text { Estimate }\end{array}$ & Durbin-Watson \\
\hline 1 & $.712^{3}$ & .507 & \multicolumn{4}{|c|}{.490} & 1.90413 & 1.638 \\
\hline
\end{tabular}
a.Predictors: (Constant), Saluran_Distribusi, Diferensiasi_Produk
b. DependentVariable: Loyalitas_Pelanggan

Pada tabel 8, besarnya koefisien determinasi dapat dilihat dari nilai Adjusted RSquare yaitu sebesar 0.490 yang artinya diferensiasi produk dan saluran distribusi dapat menjelaskan loyalitas pelanggan sebesar $49.0 \%$ dan sisanya $51.0 \%(100-49,0)$ dipengaruhi oleh variabel lain di luar dari penelitian ini seperti:kepuasan pelanggan, merek, dan harga.

\section{Pembahasan Hasil Penelitian}

Hasil uji signifikan parsial diperoleh bahwa diferensiasi produk berpengaruh positif dan signifikan terhadap loyalitas pelanggan CV. Makmur Auto Sejahtera Medan.Hal ini dibuktikan dari perolehan nilai thitung 4,834 lebih besar dari tabel 1.67065 dan nilai signifikan sebesar 0,000 lebih kecil dari 0,05.

Hasil uji signifikan parsial diperoleh bahwa saluran distribusi berpengaruh positif dan signifikan terhadap loyalitas pelanggan CV. Makmur Auto Sejahtera Medan.Hal ini dibuktikan dari perolehan nilai $t_{\text {hitung }} 4,818$ lebih besar dari $t_{\text {tabel }} 1.67065$ dan nilai signifikan sebesar 0,000 lebih kecil dari 0,05. 
Hasil uji signifikan simultandiperoleh bahwa diferensiasi produk dan saluran distribusi secara simultan berpengaruh positif dan signifikan terhadap loyalitas pelanggan CV. Makmur Auto Sejahtera Medan.Hal ini dibuktikan dari perolehan nilai $\mathrm{F}_{\text {hitung }}$ 30,308 lebih besar dari $t_{\text {tabel }} 3,15$ dan nilai signifikan sebesar 0,000 lebih kecil dari 0,05.

\section{KESIMPULAN}

Kesimpulan dalam penelitian ini adalah

1. Hasil analisis regresi linear berganda diperoleh persamaan yaitu Loyalitas Pelanggan $=0,108+0,249$ DiferensiasiProduk + 0,383SaluranDistribusi+ $\mathrm{e}$.

2. Hasil uji signifikan simultan diperoleh bahwa diferensiasi produk dan saluran distribusi secara simultan berpengaruh positif dan signifikan terhadap loyalitas pelanggan CV. Makmur Auto Sejahtera Medan. Hal ini dibuktikan dari perolehan nilai $\mathrm{F}_{\text {hitung }}$ 30,308 $>t_{\text {tabel }} 3,15$ dan nilai signifikan sebesar $0,000<0,05$.

3. Hasil uji signifikan parsial diperoleh bahwa diferensiasi produk berpengaruh positif dan signifikan terhadap loyalitas pelanggan CV. Makmur Auto Sejahtera Medan. Hal ini dibuktikan dari perolehan nilai $\mathrm{t}_{\text {hitung }} 4,834>\mathrm{t}_{\text {tabel }} 1.67065$ dan nilai signifikan sebesar 0,000 $<0,05$.

4. Hasil uji signifikan parsial diperoleh bahwa saluran distribusi berpengaruh positif dan signifikan terhadap loyalitas pelanggan CV. Makmur Auto Sejahtera Medan. Hal ini dibuktikan dari perolehan nilai $\mathrm{t}_{\text {hitung }} 4,818>\mathrm{t}_{\text {tabel }} 1.67065$ dan nilai signifikan sebesar 0,001 $<0,05$.

5. Hasil uji koefisien determinasi diperoleh bahwa diferensiasi produk dan saluran distribusi dapat menjelaskan loyalitas pelanggan sebesar $49.0 \%$ dan sisanya $51.0 \%$ dipengaruhi oleh variabel lain di luar dari penelitian ini seperti kepuasan pelanggan, merek, dan harga.

\section{DAFTAR PUSTAKA}

Alma, Buchari. 2016. Manajemen Pemasaran dan Pemasaran Jasa. Edisi Revisi. Alfabeta. Bandung.

Ardino, Dhia Urrahman dan Nina Maharani. 2018. Pengaruh Saluran Distribusi Terhadap Loyalitas Konsumen CV. Kaos Kosong Bandung. Prosiding Manajemen. ISSN: 2460 -6545. Volume 4 No. 2 Tahun 2018.

Arief dan Rakhman Kurniawan. 2018. Dasar-Dasar Marketing: Segala Hal Tentang Marketing dan Sales. Cetakan Ke-1. Yogyakarta: Quadrant.

Assauri, Sofyan. 2017. Manajemen Pemasaran: Dasar, Konsep \& Strategi. Cetakan Ketigabelas. PT. Rajagrafindo Persada. Jakarta.

Dejawata, Thariz Baharmal, Srikandi Kumadji, dan Yusri Abdillah. 2014. Pengaruh Diferensiasi Produk Terhadap Kepuasan Pelanggan dan Loyalitas Pelanggan. Jurnal Administrasi Bisnis (JAB). Volume 17 No. 2 Tahun 2014.

Diana, Nita, Silvya L. Mandey, dan Rotinsulu J. Jorie. 2017. Analisis Pengaruh Strategi Produk, Harga, Promosi, Saluran Distribusi Terhadap Loyalitas Konsumen (Studi Kasus pada Koran Radar Manado). Jurnal EMBA. Volume 5 No. 2 Tahun 2017.

Dimyati, Mohamad. 2018. Pendekatan Hayati: Strategi Pemasaran Untuk Menghadapi Persaingan Yang Dinamis. Mitra Wacana Media. Bogor. 
Ghozali, Imam. 2013. Aplikasi Analisis Multivariat dengan Program SPSS 21. Cetakan Ketujuh. Badan Penerbit Universitas Diponegoro. Semarang.

Hasan, Ali. 2014. Marketing dan Kasus-Kasus Pilihan. PT Indeks. Jakarta.

Hurriyati, Ratih. 2013. Bauran Pemasaran dan Loyalitas Konsumen. Bandung: Alfabetha.

Kartajaya, Hermawan. 2014. Positioning, Diferensiasi, dan Brand. Jakarta: PT. Gramedia Pustaka Utama.

Kotler, Philip dan Kevin Lane Keller. 2013. Manajemen Pemasaran. Edisi-13. Jilid-2. Penerjemah Bob Sabran. Jakarta: Erlangga.

Manap, H. Abdul. 2016. Revolusi Manajemen Pemasaran. Edisi Pertama. Mitra Wacana Media. Jakarta.

Muntaha, Atika Sidratul. 2018. Pengaruh Strategi Diferensiasi Terhadap Loyalitas Konsumen Bisnis Jasa Pengiriman PT. POS Indonesia (PERSERO) Pekanbaru. JOM FISIP. Volume 5 Edisi 1 Tahun 2018.

Priyatno, Duwi. 2016. SPSS Handbook: Analisis Data, Olah Data \& Penyelesaian KasusKasus Statistik. Cetakan Kesatu. Mediakom. Yogyakarta.

Setiyaningrum, Ari, Jusuf Udaya, dan Efendi. 2015. Prinsip-Prinsip Pemasaran. Andi. Yogyakarta.

Siregar, Syofian. 2017. Statistik Parametrik Untuk Penelitian Kuantitatif: Dilengkapi dengan Perhitungan Manual dan Aplikasi SPSS versi 17. Cetakan Kelima. Bumi Aksara. Jakarta.

Sudaryono. 2018. Manajemen Pemasaran Teori dan Implementasi. Edisi Kesatu. Andi. Yogyakarta.

Sujarweni, Wiratna. 2015. Metodologi Penelitian Bisnis Ekonomi. Cetakan Kesatu. Pustaka Baru. Yogyakarta.

Sunyoto, Danang. 2014. Dasar-Dasar Manajemen Pemasaran: Konsep, Strategi, dan Kasus. Cetakan Ke-4. Jakarta: PT. Buku Seru.

Tjiptono. 2014. Pemasaran Jasa: Prinsip, Penerapan, dan Penelitian. Edisi Kesatu. Andi. Yogyakarta.

Tjiptono, Ferry dan Gregorius Chandra. 2012. Pemasaran Strategik. Edisi-II. Yogyakarta: Andi.

Tunggal, Amin Widjaja. 2012. Dasar-Dasar Customer Relationship Management (CRM). Jakarta : Harvindo

Wardoyo, Dwityas Adi Kusumo dan Saryadi. 2016. Pengaruh Kualitas Produk, Harga, dan Saluran Distribusi Terhadap Loyalitas Pelanggan Majalah SWA Melalui Variabel Kepuasan Pelanggan (Studi Kasus pada Pelanggan Majalah SWA di DKI Jakarta). Jurnal Administrasi Bisnis (JAB). Volume 1 No. 1 Tahun 2016.

Wibowo, Lili Adi dan Donni Juni Priansa. 2017. Manajemen Komunikasi dan Pemasaran. Cetakan Kesatu. Alfabeta. FL. Titik. 2017. Marketing Plan! Dalam Bisnis. Edisi 
Ketiga. PT. Elex Media Komputindo. Jakarta. 